\title{
ENVIRONMENTAL CRIMINAL LAW IN THE EUROPEAN UNION
}

\author{
Avrupa Birliği Çevre Ceza Hukuku
}

\section{Güneş OKUYUCU ERGÜN*}

\begin{abstract}
Over the past decades, environmental offences have increasingly extended beyond the borders of the Member States. It has been observed that the existing systems of penalties have not been sufficient, and the availability of criminal penalties was required, to achieve complete compliance with the laws for the protection of the environment. As a result, the European environmental criminal law has gone through a remarkable development over the past decades at both EU and Member State levels. This paper suggests that, although the Directive 2008/99/EC, which is the main legal instrument of the EU environmental criminal law, was an important step forward in the protection of environment through criminal law, it may be criticised for its administrative dependence and lack of autonomous or independent approach both in terms of offences and their sanctions.
\end{abstract}

Keywords: Environmental Criminal Law, Protection of Environment, European Union, Polluter-Pays Principle, Liability of Legal Persons for Environmental Offences

\section{ÖZET}

Avrupa Birliği'nde son birkaç on yıldır çevre suçları giderek artan bir biçimde Üye Ülkelerin sınırlarını aşmaktadır. Çevrenin korunması ile ilgili mevzuata tam uyum sağlanması için mevcut ceza sistemlerinin yeterli olmadığı ve ceza hukuku yaptırımlarının gerekli olduğu bu süreçte gözlemlenmiştir. Böylece, Avrupa çevre ceza hukuku son birkaç on yılda hem $\mathrm{AB}$ hem de Üye Ülkeler düzeyinde önemli bir gelişme göstermiştir. $\mathrm{Bu}$ çalışmada, $\mathrm{AB}$ Çevre ceza hukukunun en önemli hukuki enstrümanlarından

Makale Geliş Tarihi: 16.06.2021 Makale Kabul Tarihi: 05.07.2021.

* Assoc. Prof., University of Ankara, Faculty of Law, Criminal and Criminal Procedural Law. (okuyucu@law.ankara.edu.tr, ORCID: 0000-0001-5401-2312) 
olan 2008/99/EC sayılı Yönerge'nin çevrenin ceza hukuku vasıtasıyla korunmasında önemli bir araç olmasına karşın, idari bağımlılığı ve suçlar ve yaptırımları bakımından otonom ve bağımsız bir yaklaşım sergilememesi dolayısıyla eleştiriye açık olduğu vurgulanmaktadır.

Anahtar Kelimeler: Çevre Ceza Hukuku, Çevrenin Korunması, Avrupa Birliği, Kirleten Öder İlkesi, Tüzel Kişilerin Çevre Suçlarından Sorumluluğu

\section{INTRODUCTION}

The EU is one of the leading destinations or transit hubs for illegal trade linked with environmental crimes. ${ }^{1}$ The effects of environmental offences committed in one Member State naturally and easily go beyond the borders of such State as they may cause substantial damage to the air, soil, water, animals or plants.

Environmental criminal law is one of the most "legally complex, politically sensitive and significant in practice" areas of the EU law. ${ }^{2}$ Experience has shown that the existing systems of penalties have not been sufficient, the availability of criminal penalties was required, to achieve complete compliance with the laws for the protection of the environment. ${ }^{3}$ As a result, the European environmental criminal law has gone through a remarkable development over the past decades and it has changed from a system where its role was originally reduced to back up administrative obligations as a supplement to sectoral environmental legislation, towards more autonomous provisions with a more prominent place in criminal codes. ${ }^{4}$

In this paper, we will analyse various aspects of the protection of environment through criminal law in the EU. The first part will provide an

1 The natural resources of Member States (such as Romania or Poland), and the significant demand for cheap waste disposal in certain Member States (such as Italy, Hungary and Germany) make Europe appealing for traffickers. See Lorenzo Colantoni and Margherita Bianchi, 'Fighting Environmental Crime in Europe. Preliminary Report' 5 <https://www.iai.it/en/pubblicazioni/fighting-environmental-crime-europe> accessed 17 February 2021.

2 Holger Tobias Weiß, 'EC Competence for Environmental Criminal Law' (PhD Thesis, College of Europe 2006) 4 <https://www.coleurope.eu/content/StudyProgrammes/law/studyprog/pdf/Weiss_Holger_t hesis.pdf $>$ accessed 18 February 2021.

3 Recital 3 of Directive 2008/99/EC of the European Parliament and of the Council of 19 November 2008 on the protection of the environment through criminal law 2008 (328).

4 Michael Faure, 'The Development of Environmental Criminal Law in the EU and Its Member States' (2017) 26 Review of European, Comparative \& International Environmental Law 139, 145. 
historical background of the subject. The second and third parts will deal with the environmental offenses and the sanctions for such offences in the EU legislation.

\section{HISTORICAL BACKGROUND}

EU environmental criminal law dates back to 1970s, when environmental laws often had a strongly administrative character. For a long time, criminal law was widely considered as a safe harbour of national sovereignty, shielded against influences from the EU law. ${ }^{5}$ Prior to the European Court of Justice's (ECJ) judgment in the Environmental Crime Case $^{6}$ of 2005, the principle of sovereignty was interpreted as an obstacle for the union to introduce criminal sanctions to enforce the EU law. ${ }^{7}$

In 2003, the Framework Decision 2003/80/JHA on the protection of the environment through criminal law was adopted. ${ }^{8}$ It required Member States to take necessary measures to establish certain environmental offences as criminal offences under their domestic laws. However, a few months after its adoption, the Framework Decision has been subject of a dispute between the Commission and the Council. In April 2003, the Commission sought the annulment of the Framework Decision before the ECJ by alleging that it was based on wrong legal bases. As a result, the ECJ annulled the Framework Decision with the reasoning that its adoption under the third pillar provisions infringed Article 47 of the Treaty on European Union. ${ }^{9}$

The Environmental Crime Case was a critical milestone in the history of environmental criminal law in the EU, because the ECJ concluded that, although, as a general rule, neither criminal law nor the rules of criminal procedure fall within the Community's competence, this does not prevent the Community legislature from taking measures which relate to the criminal law of the Member States which it considers necessary in order to ensure that the rules which it lays down on environmental protection are fully effective. ${ }^{10}$

$5 \quad$ Weiß (n 3$) 4$.

6 Case C- 176/03, Commission of the European Communities v Council of the European Union, ECR [2005], I-07879.

7 Jacob Öberg, 'Criminal Sanctions in the Field of EU Enviromental Law' (2012) 2 New Journal of European Criminal Law 405.

8 Council Framework Decision 2003/80/JHA of 27 January 2003 on the protection of the environment through criminal law, Official Journal, L 29, 5.2.2003, 55-58.

9 Para. 53 of Case C- 176/03.

10 Para. 48 of Case C- 176/03. 
This statement had an important impact on the nature of the EU legislation on environmental criminal law since it permitted the adoption of a directive (rather than a framework decision), which could be adopted by the Council with qualified majority instead of unanimity; which would be subject to the approval of the Parliament (rather than only consultation with the Parliament); and which, if not properly transposed into national law, would empower the Commission to bring an infringement case against a Member State before the EJC. ${ }^{11}$

In 2008, the Directive 2008/99/EC on the protection of the environment through criminal law ${ }^{12}$ was adopted to replace the Framework Decision based on the Environmental Crime Case judgment of the ECJ. This Directive, which is currently the main legal instrument of the EU law on this subject, obliges Member States to provide for criminal penalties in their national legislation in respect of serious infringements of the EU's environmental legislation.

\section{CRIMINAL OFFENSES}

Directive 2008/99/EC provides a minimum set of environmental offences which are considered as criminal offences throughout the EU. Such offences include:

(i) the discharge, emission or introduction of a quantity of materials or ionising radiation into air, soil or water;

(ii) the collection, transport, recovery or disposal of hazardous waste;

(iii) the shipment of noticeable quantities of waste;

(iv) the operation of a plant in which a dangerous activity is carried out or in which dangerous substances or preparations are stored or used;

(v) the production, processing, handling, use, holding, storage, transport, import, export or disposal of nuclear materials or other hazardous radioactive substances;

(vi) the killing, destruction, possession or taking of specimens of protected wild fauna or flora species;

11 Helge Elisabeth Zeitler, 'Environmental Criminal Law' (2006) Vol. 77 Revue internationale de droit penal 255, 257.

12 Directive 2008/99/EC of the European Parliament and of the Council of 19 November 2008 on the protection of the environment through criminal law, 28-37. 
(vii) trading in specimens of protected wild fauna or flora species;

(viii) any conduct which causes the significant deterioration of a habitat within a protected site; and

(ix) the production, importation, exportation, placing on the market or use of ozone-depleting substances.

The Commission suggests that "environmental crime" cover acts which "breach environmental legislation and cause significant harm or risk to the environment and human health" ${ }^{13}$, and since the Directive 2008/99/EC, as listed above, focuses on crimes in relation to pollution, waste, use or release of dangerous substances, protected species and habitats, its coverage appears uncertain and the categorization unclear, not least because overlaps are very common (i.e., the illegal use of fuel oil mixed with waste oil readily causes other environmental damage, such as air pollution). ${ }^{14}$

As the Directive 2008/99/EC provides for minimum rules, the Member States are free to adopt more stringent measures for the protection of the environment through criminal law.

Another piece of EU legislation relating to environmental criminal offences is the Ship-Source Pollution Directive. ${ }^{15}$ It creates rules that are applicable throughout the Union on the imposition of penalties in the event of discharges of oil or other polluting substances from ships.

Pursuant to the Directive 2008/99/EC, in order for the environmental offences referred to in the Directive to constitute a crime, they must have been (a) unlawful, and (b) committed intentionally or with at least serious negligence.

In this context, "unlawful" refers to a breach of EU or national laws that give effect to the EU legislation referred to in the Annexes to Directive 2008/99/EC. Annex A of the Directive lists 61 Directives and 8 Regulations, the oldest one of which dating back to $1970 .{ }^{16}$ They cover areas including, among others, the emission of pollutants, disposal of waste, dangerous

13 See the IPEC report: 'Report on Environmental Crime in Europe' $<$ https://www.europol.europa.eu/publications-documents/report-environmental-crime-ineurope > accessed 17 February 2021.

14 Colantoni and Bianchi (n 2).

15 Directive 2005/35/EC of the European Parliament and of the Council of 7 September 2005 on ship-source pollution and on the introduction of penalties for infringements; Official Journal, L 255, 30.9.2005, 11-21.

16 Council Directive 70/220/EEC of 20 March 1970 on the approximation of the laws of the Member States on measures to be taken against air pollution by emissions from motor vehicles; Official Journal, L 76, 6.4.1970, 1. 
substances, conservation of wild birds, air pollution, waste-water treatment, protection of waters, conservation of natural habitats and of wild fauna and flora, landfill of waste, substances that deplete the ozone layer and shipments of waste. Annex B of the Directive lists the legislation adopted pursuant to the Euratom Treaty, the infringement of which constitutes unlawful conduct. They include three Council Directives on the dangers arising from ionising radiation, the control of high-activity sealed radioactive sources and orphan sources and the shipments of radioactive waste and spent fuel. ${ }^{17}$

To meet the condition of being unlawful, the relevant environmental offence must violate either the legislation listed in the annexes of the Directive or a law, an administrative regulation of a Member State or a decision taken by a competent authority of a Member State that gives effect to the legislation referred to in the annexes. ${ }^{18}$

The "unlawfulness" condition of environmental crimes has been subject to criticisms by certain scholars.

Firstly, it was criticised for being unclear and therefore susceptible of being differently interpreted by Member States, so that some criminalise certain acts that others classify as administrative misconduct for which they merely impose fines. ${ }^{19}$ Under the Member States' national laws, the punishable conduct is often not fully described in the criminal law provision itself but also the environmental laws or in an administrative decision giving effect to that law. This could lead to complexity and ambiguity as to what exactly is punishable, and it might be problematic under the principle of legality enshrined in Article 49 of the EU Charter of Fundamental Rights. ${ }^{20}$

17 Council Directive 96/29/Euratom of 13 May 1996 laying down basic safety standards for the protection of the health of workers and the general public against the dangers arising from ionising radiation (Official Journal, L 159, 29.6.1996, 1); Council Directive 2003/122/Euratom of 22 December 2003 on the control of high-activity sealed radioactive sources and orphan sources (Official Journal, L 346, 31.12.2003, 57) and Council Directive 2006/117/Euratom of 20 November 2006 on the supervision and control of shipments of radioactive waste and spent fuel (Official Journal, L 337, 5.12.2006, 21).

18 Article 2(a) of the Directive 2008/99/EC.

19 Interview with Florence Schulz, 'Detecting Environmental Crime Is Quite a Problem' (24 March 2020) <https://www.euractiv.com/section/energyenvironment/interview/environmental-law-expert-detecting-environmental-crime-is-quitea-problem/> accessed 17 February 2021.

20 'EU Environmental Criminal Law - Presidency Report' $<$ https://data.consilium.europa.eu/doc/document/ST-12801-2019-INIT/en/pdf > accessed 13 February 2021. 
Moreover, it was also criticised because of its administrative dependence. The Directive does not contain autonomous or independent crimes in the sense that a conduct is criminalised, even if the unlawfulness condition is not met (i.e. even if the conduct is in line with an administrative authorisation). ${ }^{21}$ The reference to "unlawful" seems to be tautologous as it a reference to the requirement that there must be a defined breach of EU environmental law, rather than an attempt to establish new standards of conduct. ${ }^{22}$ As a result, for example, there could be a case of serious pollution, but if it did not at the same time constitute a violation of an administrative obligation, intervention by the criminal law would not be possible. ${ }^{23}$

Pursuant to Article 3 of the Directive 2008/99/EC, only offences which are committed "intentionally or with at least serious negligence" can be considered as a criminal offence.

The Ship-Source Pollution Directive ${ }^{24}$ makes a slightly different formulation as regards this element of the environmental offences. It provides that the ship-source discharges of polluting substances are regarded as infringements if committed with "intent, recklessly or with serious negligence. " 25

The ECJ analysed, by its decision of 3 June 2008, the concepts of "intent", "recklessness" and "serious negligence" for the purposes of this provision of the Ship-Source Pollution Directive. ${ }^{26}$ Firstly, the ECJ pointed out that the fact that these terms are not defined in the Directive is not necessarily a shortcoming since those concepts are fully integrated into, and used in, the Member States' respective legal systems. ${ }^{27}$ Accordingly, the ECJ

21 See Armelle Gouritin and Paul De Hert, 'Directive 2008/99/EC of 19 November 2008 on the Protection of the Environment through Criminal Law: A New Start for Criminal Law in the European Community?' [2009] elni Review 22, 22-27.

22 Paul James Cardwell, D French and M Hall, 'Tackling Environmental Crime in the European Union: The Case of the Missing Victim?' (2011) 23 113, 5.

23 Faure (n 5) 140.

24 Directive 2005/35/EC of the European Parliament and of the Council of 7 September 2005 on ship-source pollution and on the introduction of penalties for infringements; Official Journal, L 255, 30.9.2005, 11-21.

25 Article 4 of the Directive 2005/35/EC.

26 ECJ, C-308/06 (Grand Chamber), preliminary ruling, The Queen on the application of International Association of Independent Tanker Owners (Intertanko), International Association of Dry Cargo Shipowners (Intercargo), Greek Shipping Co-operation Committee, Lloyd's Register, International Salvage Union v Secretary of State for Transport, 3 June 2008, § 77, <http://curia.europa.eu/jurisp/cgi-bin/form.pl?lang=en $>$ accessed 21 February 2021

27 Para. 74 of Decision C-308/06. 
defined "serious negligence" as "an unintentional act or omission by which the person responsible commits a patent breach of the duty of care which he should have and could have complied with in view of his attributes, knowledge, abilities and individual situation. ${ }^{, 28}$ The Court ruled the use of such concepts in the Directive without defining them was not contrary to the general principle of legal certainty. ${ }^{29}$

\section{SANCTIONS}

\section{A. Criminal Penalties}

As stated in the preamble of the Directive 2008/99/EC, experience has shown that the existing systems of penalties have not been sufficient to achieve complete compliance with the laws for the protection of the environment, and such compliance should be strengthened by the availability of "criminal penalties", in addition to administrative penalties or a compensation mechanism under civil law. ${ }^{30}$

Such reliance of the Directive 2008/99/EC on criminal law is criticised in the legal literature. According to certain scholars, it is problematic that the Directive clearly holds in its recitals that only criminal law can demonstrate a social disapproval of a qualitatively different nature compared to administrative penalties or compensation mechanisms under civil law. As a result of such approach, the Directive did not address situations where administrative sanctions such as fine or other sanctions can also provide an effective deterrent. Relying too strongly on criminal law was criticised for potentially leading to over-criminalisation..$^{31}$ Although the seriousness of certain environmental offences demands an effective response from the Member States, all three main systems of sanctions - civil, administrative and criminal - should be made available in the environmental field in order to optimise enforcement. ${ }^{32}$

On the other hand, accumulation of these different systems of sanctions may sometimes be a sensitive matters, especially between administrative and

28 Para. 77 of Decision C-308/06.

29 Para. 80 of Decision C-308/06.

30 Recital 3 of the Directive 2008/99/EC.

31 Christiane Gerstetter and others, 'Environmental Crime and the EU: Synthesis of the Research Project "European Union Action to Fight Environmental Crime" EFFACE' 32 <https://www.ecologic.eu/13614> accessed 13 April 2021.

32 Ricardo M Pereira, 'The Harmonisation of Substantive Environmental Criminal Law and Penalties', Environmental criminal liability and enforcement in European, and international law (Brill Nijhoff 2015) 346. 
criminal sanctions. The question of possible accumulation of criminal and administrative measures raises issues related to human rights law, depending on the nature given to the measure and the effect that the measure may have in the person to whom it has been imposed, if the measure applied has a punitive nature, including the principle of non bis in idem, provided under Article 4 of Protocol No. 7 to the Europen Convention on Human Rights, which holds that a person cannot be punished twice for the same facts. ${ }^{33}$ In order to decide whether an administrative sanction can be imposed at the same time as a criminal penalty, the Member States usually refer to the interest protected, the national jurisprudence and as the jurisprudence of the European Court of Human Rights. ${ }^{34}$

The Directive 2008/99/EC requires Member States to punish the environmental offence by "effective, proportionate and dissuasive criminal penalties ". ${ }^{35}$ However, the specific types of sanctions that the Member States are required to incorporate into their national legislation are not stated in the Directive. Some scholars consider that the fact that the Directive does not harmonise sanctions (e.g. by providing rules on minimum sanctions) is a weakness, as there are substantial differences with respect to what the law defines as maximum penalties for various environmental crimes in Member States. ${ }^{36}$ However, some other scholars argue that even though the Directive does not impose any particular classification of offences on Member States, a purposive or teleological reading of that instrument appears to indicate that the EU institutions consider the offences contained therein to be particularly serious and hence that they should be considered indictable/serious crimes, or at least "major offences". ${ }^{37}$ The Directive requires the Member States to ensure that inciting, aiding and abetting the environmental offences are also punishable as a criminal offence. ${ }^{38}$

Although Environmental crimes are also often wrongly perceived as "victimless" 39 , they cause huge reversible or irreversible environmental impacts, including the pollution and degradation or disturbance of the ecological balance; species on the verge of extinction and a consequent reduction in biodiversity; contamination of the food chain; and negative

33 Milieu and Huglo Lepage, 'Measures Other than Criminal Ones in Cases Where Environmental Community Law Has Not Been Respected in the EU Member States' 73, 14.

34 Milieu and Huglo Lepage (n 34) 15.

35 Article 5 of the Directive 2008/99/EC.

36 Gerstetter and others (n 32) 32.

37 Pereira (n 33) 220

38 Article 4 of the Directive 2008/99/EC.

39 Cardwell, French and Hall (n 23) 113. 
impacts on local community livelihood and on sustainable development; other social, economic and political impacts, such as lower income in the hands of legitimate businesses or loss of tax revenue that has negative effects on societies and services for EU citizens, as well as the damage caused to the reputation of the EU and of its member states are also damaged. ${ }^{40}$

Since the Member States are responsible for prosecuting the environmental crimes, the cooperation and coordination between the Member States, their law enforcement agencies and the networks of environmental professionals are critical to effective combat against such crimes. In that regard, the networks of environmental professionals, such as the EU Network for the Implementation and Enforcement of Environmental Law (IMPEL), the EU Forum of Judges for the Environment (EUFJE) and the European Network of Prosecutors for the Environment (ENPE), play an important role in sharing best practice and developing methodologies for effective enforcement. ${ }^{41}$

\section{B. Liability of Legal Persons}

The Directive 2008/99/EC requires that the legal persons can be held liable for environmental offences where such offences have been committed for their benefit by any person who has a leading position within the legal person, acting either individually or as part of an organ of the legal person. ${ }^{42}$

The Directive also requires the Member States to ensure that legal persons can be held liable where the lack of supervision or control has made possible the commission of an environmental offence for the benefit of the legal person by a person under its authority. ${ }^{43}$

The Directive defines "legal person" as "any legal entity having such status under the applicable national law, except for States or public bodies exercising State authority and for public international organizations." 44 Therefore, public organisations are excluded from the scope of the Directive. Such an exclusion is subject to criticism in the legal literature. ${ }^{45}$

40 Colantoni and Bianchi (n 2) 9.

${ }^{41}$ See 'Cooperation with Other Environmental Enforcement Networks' <https://www.eufje.org/index.php?option=com_content\&view=article\%20\&id=65\&Itemid $=256 \&$ lang=en $>$ accessed 8 December 2021 .

42 Article 6(1) of the Directive 2008/99/EC.

43 Article 6(2) of the Directive 2008/99/EC.

44 Article 2(d) of the Directive 2008/99/EC.

45 See Gouritin and De Hert (n 22) 25. 
Liability of legal persons does not exclude criminal proceedings against natural persons who are perpetrators, inciters or accessories in the relevant environmental offences. ${ }^{46}$

Similar to the penalties for individuals, the Directive does not provide specific types of sanctions that the Member States are required to incorporate into their national legislation regarding the legal persons. In that regard, the Directive repeats the principle applicable for the individuals (i.e. the penalties being effective, proportionate and dissuasive) for the legal persons as well. ${ }^{47}$ However, such penalties are not required to be criminal penalties. Indeed, some Member States' legal orders do not permit criminal penalties for legal persons. Therefore, the Directive leaves the choice of the penalty's nature (criminal or administrative) $)^{48}$ to the Member States. ${ }^{49}$

Although making legal persons accountable for environmental offences is helpful, it should not be considered as a substitute for the prosecution of culpable individuals. It is argued in the literature that when corporations commit environmental crimes, culpable individuals, if supported by the law and the facts, should also be subject to criminal charges, since the possibility that corporate officials could be jailed for their wrongdoing is the strongest deterrent for environmental crime. ${ }^{50}$

The Ship-Source Pollution Directive also envisages liability of legal persons for environmental offence. The Directive 2005/35/EC, as amended by Directive 2009/123/EC ${ }^{51}$, required Member States to introduce rules on the liability of legal persons for ship-source pollution related offences.

46 Article 6(3) of the Directive 2008/99/EC.

47 Article 7 of the Directive 2008/99/EC.

48 For a comparison of the effectiveness of administrative or civil fines and criminal sanctions in the enforcement of Union environmental law, see Öberg (n 8) 418. For a study on 'Criminal, administrative and civil law approaches to addressing environmental crime in comparison', see Gerstetter and others (n 32) 31.

49 Gouritin and De Hert (n 22) 26.

50 David M Uhlmann, 'Protection of the Environment through Criminal Law: An American Perspective' (2016) 6 International Law Review 144, 160.

51 Directive 2009/123/EC of the European Parliament and of the Council of 21 October 2009 amending Directive 2005/35/EC on ship-source pollution and on the introduction of penalties for infringements, Official Journal, L 280, 27.10.2009, 52-55. 


\section{Polluter-Pays Principle}

The Environmental Liability Directive ${ }^{52}$ (ELD) is another important piece of EU legislation relating to environmental criminal offences. Although the ELD is not an instrument of criminal law, it aims at preventing environmental crime by making the operators liable for the consequences of their actions. It lays down rules based on the "polluter-pays" principle, which means that an operator ${ }^{53}$ whose activity has caused the environmental damage or the imminent threat of such damage is to be held financially liable, and it must take the necessary preventive or remedial action and bear all the related costs.

The origins of the polluter-pays principle date back to 1920s, but the principle came into modern parlance with the United Nation's 1992 Rio Declaration on Environment and Development ${ }^{54}$, which, in Principle 16, referred to the approach that the polluter should, in principle, bear the cost of pollution, with due regard to the public interest and without distorting international trade and investment. ${ }^{55}$

The ELD defines environmental damage as (i) damage that significantly affects the environmental status of water resources; (ii) damage to land creating a significant risk to human health; (iii) damage to protected species and natural habitats; and (iv) the discharge of pollutants into the air, inland surface water and groundwater, and any deliberate release into the environment of genetically modified organisms.

Pursuant to the ELD, the liability may occur if an environmental damage is caused by any of the activities listed in Annex III of the directive, such as energy industries, production and processing of metals, mineral industries, chemical industries and waste management; or if and environmental damage to protected species and natural habitats is caused by certain occupational

52 Directive 2004/35/CE of the European Parliament and of the Council of 21 April 2004 on environmental liability with regard to the prevention and remedying of environmental damage; Official Journal, L 143, 30.4.2004, 56-75.

53 The ELD defines 'operator' as any natural or legal, private or public person who operates or controls the occupational activity or, where this is provided for in national legislation, to whom decisive economic power over the technical functioning of such an activity has been delegated, including the holder of a permit or authorisation for such an activity or the person registering or notifying such an activity (Article 2.6 of the ELD).

54 Rio Declaration on Environment and Development, Annex I of the United Nations Conference on Environment and Development, Rio de Janeiro, 3-14 June 1992.

55 Karen Hulme and Damien Short, 'Ecocide and the "polluter Pays" Principle: The Case of Fracking' (2014) 23 Environmental Scientist 7, 8. 
activities. The ELD requires the operators to take preventive action and bear the costs of clean-up measures.

The ELD, and therefore its polluter-pays principle, does not apply in certain exceptional cases, such as damages caused by an act of armed conflict, hostilities, civil war or insurrection; or a natural phenomenon of exceptional, inevitable and irresistible character. ${ }^{56}$

\section{CONCLUDING REMARKS}

Preventing and remedying environmental damage contributes to implementing the objectives and principles of the Community's environment policy as set out in the Treaty establishing the European Community. As a matter of fact, Article 174(2) of the Treaty requires the Community policy on the environment to aim at a high level of protection. In that regards, the Directive 2008/99/EC was an important step forward in the protection of environment through criminal law. It can be seen as a sign of consolidation of criminal law and "Europeanization" of the protection of the environment. ${ }^{57}$

Such trend for "Europeanization" of the protection of the environment was also triggered by the strong public opinion in support for state intervention to tackle serious violations of environmental law. For example, a 2008 Eurobarometer survey in the 27 Member States suggests that $82 \%$ of the respondents regard harmonisation of environmental law at the EU level as necessary; and the highest proportion of respondents (37\%) supported the introduction of heavier fines for offenders as an effective way to tackle environmental problems. ${ }^{58}$

However, the Directive may be criticised for not fully achieving the objectives that it originally had. Indeed, the expert study commissioned by the European Commission to assess the success of the implementation of Directive 2008/99/EC highlighted that several Member States had failed to fully transpose the Directive, and the legal sanctions applicable at the national level shown to be disproportionate or inappropriate. ${ }^{59}$

56 Article 4 of the ELD.

57 Gouritin and De Hert (n 22) 27.

58 Eurobarometer, 'Attitudes of European Citizens Towards the Environment' <https://europa.eu/eurobarometer/screen/home> accessed 6 June 2021; see Pereira (n 33) 347.

59 See 'Evaluation Study on the Implementation of Directive 2008/99/EC on the Protection of the Environment through Criminal Law by Member States' 
The Directive is also subject to criticism, such as the criticism against the "unlawfulness" condition of environmental crimes $^{60}$, its administrative dependence and lack of autonomous or independent approach both in terms of offences and their sanctions ${ }^{61}$, and over-criminalisation of EU environmental law ${ }^{62}$, as further explained in Sections II and III above.

Furthermore, instead of merely forcing Member States to criminalize environmental harm, enforcement powers should be awarded to the European Environment Agency or a similar agency to verify outcomes of the implementation of the Directive. ${ }^{63}$

Such criticism and shortcomings of the Directive 2008/99/EC led to an initiative to amend it. On 2 February 2021, the European Commission began the public consultation process on the new Environmental Crime Directive. ${ }^{64}$ The new Environmental Crime Directive is expected to be adopted by the end of 2021. In order for the new Directive to achieve its objectives, it should both include new crime categories which are not listed expressly by the Treaty (which became permissible with the adoption of the Lisbon Treaty - i.e. after the adoption of the Directive in 2008 - in line with the jurisprudence of the ECJ), and should tackle the evolving trends in environmental crime, such as the growing involvement of organised crime and the liability legal persons, as explained above. ${ }^{65}$

〈https://ec.europa.eu/info/sites/info/files/milieu_implementation_report_2013.pdf〉 accessed 17 February 2021.

60 Interview with Schulz (n 20); 'EU Environmental Criminal Law - Presidency Report' (n 21).

61 Gouritin and De Hert (n 22) 22-27.

62 Gerstetter and others (n 32) 32.

${ }^{63}$ See Faure (n 5) 145.

${ }^{64}$ See 'Environmental Crime - Improving EU Rules on Environmental Protection through Criminal Law' $\quad<$ https://ec.europa.eu/info/law/better-regulation/have-yoursay/initiatives/12779-Improving-environmental\%20-protection-through-criminal-law> accessed 15 February 2021.

65 Section III.B above. Also see European Commission, 'Evaluation Report of Directive 2008/99/EC of the European Parliament and of the Council of 19 November 2008 on the Protection of the Environment through Criminal Law' (7 February 2020) 8 <http://op.europa.eu/en/publication-detail/-/publication/504f6aa3-49c8-11ea-8aa5-

01aa75ed71a1/language-en> accessed 7 June 2021. 


\section{BIBLIOGRAPHY}

Cardwell PJ, French D and Hall M, 'Tackling Environmental Crime in the European Union: The Case of the Missing Victim?’ (2011) 23113

Colantoni L and Bianchi M, 'Fighting Environmental Crime in Europe. Preliminary Report' <https://www.iai.it/en/pubblicazioni/fighting-environmental-crimeeurope $>$ accessed 17 February 2021

'Cooperation with Other Environmental Enforcement Networks' $<$ https://www.eufje.org/index.php?option=com_content\&view=article\%20\&id $=65 \&$ Itemid=256\&lang=en $>$ accessed 8 December 2021

'Environmental Crime - Improving EU Rules on Environmental Protection through Criminal Law' <https://ec.europa.eu/info/law/better-regulation/have-yoursay/initiatives/12779-Improving-environmental\%20-protection-throughcriminal-law> accessed 15 February 2021

'EU Environmental Criminal Law - Presidency Report' <https://data.consilium.europa.eu/doc/document/ST-12801-2019-INIT/en/pdf> accessed 13 February 2021

Eurobarometer, 'Attitudes of European Citizens Towards the Environment' <https://europa.eu/eurobarometer/screen/home> accessed 6 June 2021

European Commission, 'Evaluation Report of Directive 2008/99/EC of the European Parliament and of the Council of 19 November 2008 on the Protection of the Environment through Criminal Law' (7 February 2020) <http://op.europa.eu/en/publication-detail/-/publication/504f6aa3-49c8-11ea8aa5-01aa75ed71a1/language-en> accessed 7 June 2021

'Evaluation Study on the Implementation of Directive 2008/99/EC on the Protection of the Environment through Criminal Law by Member States' $<$ https://ec.europa.eu/info/sites/info/files/milieu_implementation_report_2013. pdf $>$ accessed 17 February 2021

Faure M, 'The Development of Environmental Criminal Law in the EU and Its Member States' (2017) 26 Review of European, Comparative \& International Environmental Law 139

Gerstetter C and others, 'Environmental Crime and the EU: Synthesis of the Research Project "European Union Action to Fight Environmental Crime" EFFACE' <https://www.ecologic.eu/13614> accessed 13 April 2021

Gouritin A and De Hert P, 'Directive 2008/99/EC of 19 November 2008 on the Protection of the Environment through Criminal Law: A New Start for Criminal Law in the European Community?' [2009] elni Review 22

Hulme K and Short D, 'Ecocide and the "polluter Pays" Principle: The Case of Fracking' (2014) 23 Environmental Scientist 7 
Interview with Florence Schulz, 'Detecting Environmental Crime Is Quite a Problem' (24 March 2020) <https://www.euractiv.com/section/energyenvironment/interview/environmental-law-expert-detecting-environmentalcrime-is-quite-a-problem/> accessed 17 February 2021

Milieu and Huglo Lepage, 'Measures Other than Criminal Ones in Cases Where Environmental Community Law Has Not Been Respected in the EU Member States' 73

Öberg J, 'Criminal Sanctions in the Field of EU Enviromental Law' (2012) 2 New Journal of European Criminal Law

Pereira RM, 'The Harmonisation of Substantive Environmental Criminal Law and Penalties', Environmental criminal liability and enforcement in European, and international law (Brill Nijhoff 2015)

'Report on Environmental Crime in Europe' <https://www.europol.europa.eu/publications-documents/reportenvironmental-crime-in-europe> accessed 17 February 2021

Uhlmann DM, 'Protection of the Environment through Criminal Law: An American Perspective' (2016) 6 International Law Review 144

Weiß HT, 'EC Competence for Environmental Criminal Law' (PhD Thesis, College of Europe 2006) <https://www.coleurope.eu/content/StudyProgrammes/law/studyprog/pdf/Weis s_Holger_thesis.pdf> accessed 18 February 2021

Zeitler HE, 'Environmental Criminal Law' (2006) Vol. 77 Revue internationale de droit penal 255

Directive 2008/99/EC of the European Parliament and of the Council of 19 November 2008 on the protection of the environment through criminal law 2008 (328) 